\title{
The Absence of Quinoprotein Alcohol Dehydrogenase in Acinetobacter calcoaceticus
}

\author{
By MATTHEW BEARDMORE-GRAY AND CHRISTOPHER ANTHONY* \\ Department of Biochemistry, University of Southampton, Southampton SO9 3TU, U.K.
}

(Received 12 July 1983)

\begin{abstract}
It is shown that the unusual $\mathrm{NAD}(\mathrm{P})^{+}$-independent quinoprotein alcohol dehydrogenase, said previously to be responsible for oxidation of ethanol during growth of Acinetobacter calcoaceticus LMD 79.39, was in fact isolated from an unidentified organism which contained cytochrome $c$ and which has now been lost. Several genuine strains of $\boldsymbol{A}$. calcoaceticus do not contain cytochrome $c$ nor do they contain a quinoprotein alcohol dehydrogenase. The enzyme responsible for ethanol oxidation in these bacteria is an inducible $\mathrm{NAD}^{+}$-linked alcohol dehydrogenase.
\end{abstract}

\section{INTRODUCTION}

Acinetobacter calcoaceticus is an aerobic, Gram-negative, oxidase-negative organism able to grow on a wide range of carbon substrates including ethanol and higher alkanes but not on methanol or methane (Baumann et al., 1968b; Kennedy et al., 1975). It had been noted in previous brief communications that extracts of $A$. calcoaceticus NCIB 8250 catalyse the NAD ${ }^{+}-$ linked oxidation of normal aliphatic alcohols (Fewson, 1966) and that extracts of A. calcoaceticus 69. V catalyse a very slow hexanol-dependent reduction of dichlorophenolindophenol (Tauchert et al., 1975). Subsequently, in a very thorough study, Duine \& Frank (1981) concluded that when an organism considered to be $A$. calcoaceticus (LMD 79.39) was grown on ethanol it contained an NAD $(P)^{+}$-independent alcohol dehydrogenase which was an amine-activated quinoprotein having pyrrolo-quinoline quinone (PQQ) as its prosthetic group. Although only oxidizing methanol very poorly $\left(K_{\mathrm{m}} 200 \mathrm{~mm}\right)$, it resembled the methanol dehydrogenase of methylotrophs in all other important respects. Methanol dehydrogenase is exceptional in reacting with the proton-translocating electron transport chain at the level of cytochrome $c$, thus bypassing cytochrome $b$ (Widdowson \& Anthony, 1975; Duine et al., 1979; Anthony, 1982; BeardmoreGray et al., 1983). It might be expected, therefore, that the quinoprotein alcohol dehydrogenase of Acinetobacter calcoaceticus would interact with the cytochrome chain in a similar manner. Acinetobacter species, however, typically contain no cytochrome $c$ (Baumann et al., 1968a; Whittaker, 1971; Jones et al., 1975; Ensley \& Finnerty, 1980). This suggested that either the alcohol dehydrogenase studied by Duine \& Frank (1981) was not from $A$. calcoaceticus or that there may be an unexpected diversity in the manner of coupling quinoprotein alcohol dehydrogenases to the electron transport chain. These alternatives are investigated in the present paper.

\footnotetext{
Abbreviations: CAPS, 3-(cyclohexylamino)-1-propanesulphonic acid; CHES, 2-( $N$-cyclohexylamino)ethanesulphonic acid; HEPES, $N$-2-hydroxyethylpiperazine- $N^{\prime}$-2-ethanesulphonic acid; MOPS, 3-( $N$-morpholino)propanesulphonic acid; MES, 2-( $N$-morpholino)ethanesulphonic acid; TMPD, $N, N, N^{\prime}, N^{\prime}$-tetramethyl-pphenylenediamine; PES, phenazine ethosulphate; PMS, phenazine methosulphate.
} 


\section{METHODS}

Organisms and growth conditions. The strain of 'Acinetobacter calcoaceticus' originally supplied by the culture collection of Delft University of Technology (June, 1981) as A. calcoaceticus LMD 79.39 has been designated by us 'Strain A'. This strain was used by Duine \& Frank (1981) for characterization of the quinoprotein alcohol dehydrogenase but has since been lost by ourselves, the culture collection and other workers. Strain LMD 79.39 used in the present work was supplied by the same culture collection (October, 1982) and appears to be a genuine A. calcoaceticus. Strain LMD 70.9 is one of the strains used in the study of the quinoprotein glucose dehydrogenase by Duine et al. (1982); NCIB 10694 (=ATCC 23055) is the type strain of A. calcoaceticus; NCIB 8250 is the strain originally called 'Vibrio 01 '.

All bacteria were grown at $\mathrm{pH} 7.0$ at $30^{\circ} \mathrm{C}$ in $500 \mathrm{ml}$ volumes in 2-litre baffled flasks on an orbital shaker. The growth medium (formula provided by Mrs G. Hardy, University of Hull) contained the following (per litre): $8 \mathrm{~g}$ $\mathrm{KH}_{2} \mathrm{PO}_{4}, 2 \mathrm{~g}\left(\mathrm{NH}_{4}\right)_{2} \mathrm{SO}_{4}$ and $2 \mathrm{ml}$ of the trace element mixture described by Beggs \& Fewson (1977). After sterilization of the medium, sterile $\mathrm{MgSO}_{4} \cdot 7 \mathrm{H}_{2} \mathrm{O}(40 \%, \mathrm{w} / \mathrm{v})$ was added to a final concentration of $2 \mathrm{~g} \mathrm{I}^{-1}$. The carbon source was either sodium succinate $(50 \mathrm{~mm})$ or ethanol $(0.5 \%, \mathrm{v} / \mathrm{v})$. Bacteria were harvested at the end of the exponential phase of growth, washed twice in $50 \mathrm{~mm}$-sodium phosphate buffer $(\mathrm{pH} 7 \cdot 0)$ and suspended in $25 \mathrm{~mm}$-MOPS buffer, pH 7.0, containing $5 \mathrm{mM}-\mathrm{MgCl}_{2}$.

Preparation of soluble and membrane fractions. The method was essentially that described by Widdowson \& Anthony (1975). The bacterial suspension was disrupted by sonication and whole cells were removed by centrifugation at $5000 \mathrm{~g}$ for $20 \mathrm{~min}$. The resulting supernatant was centrifuged at $200000 \mathrm{~g}$ for $1 \mathrm{~h}$ to give the soluble fraction and the membrane fraction which was suspended in $50 \mathrm{~mm}-\mathrm{MOPS}$ buffer, $\mathrm{pH} 7 \cdot 0$, containing $5 \mathrm{mM}-\mathrm{MgCl}_{2}$. Protein concentrations were determined by the method of Bradford (1976).

Measurement of respiration rates and cytochrome concentrations. Respiration rates with whole-cell suspensions were measured in a Rank $\mathrm{O}_{2}$ electrode at $30^{\circ} \mathrm{C}$ as previously described (Bolbot \& Anthony, 1980). HEPES buffer $(\mathrm{pH} 7 \cdot 0,25 \mathrm{mM})$ was used and substrates were used at $10 \mathrm{mM}$ final concentration except for ascorbate (4 mM) plus TMPD (0.4 mM). Cytochrome determinations were as described by Cross \& Anthony (1980). The absorption coefficients used for cytochromes $b$ and $d$ were those used by Ensley \& Finnerty (1980).

Assay of dye-linked alcohol dehydrogenase activity. This was done at $30^{\circ} \mathrm{C}$ using a $\mathrm{Rank} \mathrm{O}_{2}$ electrode. The assay system ( $2 \mathrm{ml}$ ) contained $36 \mu \mathrm{mol}$ Tris $/ 39 \mu \mathrm{mol}$ glycine buffer (pH 9.5), $16 \mu \mathrm{mol}$ methylamine, $0.55 \mu \mathrm{mol}$ PES and $10 \mu \mathrm{mol}$ ethanol.

Assay of $\mathrm{NAD}^{+}$-linked alcohol dehydrogenase activity. $\mathrm{NAD}^{+}$reduction was measured at $340 \mathrm{~nm}$ in a recording spectrophotometer at room temperature. The reaction mixture $(1 \mathrm{ml})$ contained $20 \mu \mathrm{mol}$ CHES buffer $(\mathrm{pH} \mathrm{9.8),}$ $1 \mu \mathrm{mol} \mathrm{NAD}{ }^{+}$and soluble protein. The reaction was initiated by addition of alcohol substrate $(1 \mu \mathrm{mol})$. For the determination of $\mathrm{pH}$ optima the following buffers (20 mM) were used: MES (pH 6.0 to 6.5), MOPS (pH 6.3 to 7.9), HEPES (pH 6.8 to 8.2 ), CHES (pH 8.6 to 10.0 ) and CAPS (pH 9.7 to $11 \cdot 1$ ).

Preparation of dye-linked alcohol dehydrogenase from strain $A$. This was done exactly as described by Duine \& Frank (1981).

\section{RESULTS AND DISCUSSION}

The first results presented below summarize a preliminary investigation of the cytochromes and enzymes from the same strain of Acinetobacter calcoaceticus as was originally used by Duine \& Frank (1981). This strain was labelled LMD 79.39. It differs in its properties from subsequent strains having the same culture collection number, but its identity cannot be investigated further because it has been lost by ourselves, the culture collection and other workers. As the work recorded below shows, and as shown independently by $\operatorname{Dr}$ J. A. Duine (personal communication), this strain was not a typical Acinetobacter calcoaceticus. It is therefore referred to as 'Strain A' in the present paper.

Properties of Strain A. Spectral analysis of whole cells, membrane fractions and soluble fractions showed that when grown on ethanol and on succinate, this strain contained cytochromes $c, b$ and $d$ (Table 1 ). When grown on ethanol, it contained a soluble NAD $(\mathrm{P})^{+}$independent alcohol dehydrogenase which could be assayed using PMS as the primary electron acceptor. It was extracted from membranes, assayed, purified and shown to have the same properties as described by Duine \& Frank (1981). The specific activity of the pure enzyme was $44.8 \mu \mathrm{mol}$ ethanol oxidized $\min ^{-1}(\mathrm{mg} \text { protein })^{-1}$. Its spectrum indicated that it was a quinoprotein having an $A_{280} / A_{345}$ ratio of $9 \cdot 1$. 
Table 1. Cytochrome content and alcohol dehydrogenase activities of various strains of Acinetobacter calcoaceticus and of 'Strain $A$ '

'Strain A' is the original strain LMD 79.39 which contains quinoprotein alcohol dehydrogenase and which does not appear to be an Acinetobacter sp. All other strains are typical Acinetobacter calcoaceticus (see text). Bacteria were harvested at or near the end of the exponential phase of growth. Some of the cytochrome $b$ observed is likely to be cytochrome $o$; this was not separately determined. The concentration of cytochrome $c$ in the soluble fraction of strain A was 40 to 80 pmol (mg protein $)^{-1}$. The specific activities of $\mathrm{NAD}^{+}$-linked alcohol dehydrogenase were measured with ethanol as substrate; the specific activities with $n$-octanol were almost identical to these. ND, Not determined. + , present (in amounts too small to determine accurately); - , absent.

\begin{tabular}{|c|c|c|c|c|c|c|c|c|}
\hline \multirow[b]{3}{*}{ Strain } & \multirow[b]{3}{*}{ Growth substrate } & \multicolumn{6}{|c|}{ Cytochrome content } & \multirow{3}{*}{$\begin{array}{c}\text { Alcohol } \\
\text { dehydrogenase } \\
{\left[\text { nmol min }{ }^{-1}\right.} \\
\left.(\text { mg protein })^{-1}\right]\end{array}$} \\
\hline & & \multicolumn{3}{|c|}{$\begin{array}{c}\text { Whole cells } \\
{\left[\mathrm{pmol}(\mathrm{mg} \text { dry wt })^{-1}\right]}\end{array}$} & \multicolumn{3}{|c|}{$\begin{array}{l}\text { Membrane fractions } \\
\left.[\text { pmol (mg protein })^{-1}\right]\end{array}$} & \\
\hline & & Cyt. $c$ & Cyt. $b$ & Cyt. $d$ & Cyt. $c$ & Cyt. $b$ & Cyt. $d$ & \\
\hline \multirow[t]{2}{*}{ 'Strain A' } & Ethanol & 750 & 750 & + & 1400 & 1820 & + & ND \\
\hline & Succinate & 412 & 600 & - & 855 & 1290 & - & ND \\
\hline \multirow[t]{2}{*}{ LMD 79.39} & Ethanol & 0 & 126 & 73 & 0 & 1323 & 882 & 960 \\
\hline & Succinate & 0 & 169 & 84 & 0 & 1132 & 881 & 0 \\
\hline \multirow[t]{2}{*}{ LMD 70.9} & Ethanol & 0 & 88 & 34 & 0 & 445 & 295 & 84 \\
\hline & Succinate & 0 & 354 & 215 & 0 & 1973 & 1384 & 0 \\
\hline \multirow[t]{2}{*}{ NCIB 10694} & Ethanol & 0 & 123 & 50 & 0 & 301 & 120 & 85 \\
\hline & Succinate & 0 & 110 & 20 & 0 & 399 & 157 & 0 \\
\hline \multirow[t]{2}{*}{ NCIB 8250} & Ethanol & 0 & 151 & 47 & 0 & 947 & 594 & 188 \\
\hline & Succinate & 0 & 370 & 148 & 0 & 571 & 532 & 0 \\
\hline
\end{tabular}

The cytochromes of $A$. calcoaceticus. The strains described here were all oxidase-negative (by conventional bacteriological tests) and none oxidized ascorbate plus TMPD, measured in an $\mathrm{O}_{2}$ electrode using whole-cell suspensions prepared from cultures grown on succinate or ethanol. All strains contained cytochromes $b$ and $d$ but none contained any cytochrome $c$ (Table 1). This is consistent with the failure to oxidize TMPD, and consistent with other published descriptions of the cytochrome content of $A$. calcoaceticus (Baumann et al., 1968 a; Whittaker, 1971; Jones et al., 1975; Ensley \& Finnerty, 1980). All these strains showed both spreading and non-spreading colony types characteristic of $\boldsymbol{A}$. calcoaceticus (Henrichsen, 1972; Henriksen, 1973).

The alcohol dehydrogenase of Acinetobacter calcoaceticus. Whole-cell suspensions of all four strains tested oxidized ethanol after growth on ethanol but not after growth on succinate. No PMS- or PES-linked (NAD ${ }^{+}$-independent) ethanol dehydrogenase activity could be detected in membranes or soluble fractions of any of these strains when using the dehydrogenase assay system based on that of Duine \& Frank (1981) (see Methods). Activity was tested for under a wide range of experimental conditions including the following. Alternative buffers tested were Tris/ $\mathrm{HCl}(50 \mathrm{mM}, \mathrm{pH} 8.0$ to 9.0 ), sodium tetrapyrophosphate $(50 \mathrm{mM}, \mathrm{pH} 9.0$ to 9.5$)$ and MOPS $(50 \mathrm{mM}, \mathrm{pH} 7.0)$. The methylamine concentration was varied $(0.5$ to $8.0 \mathrm{mM})$ and ethylamine, propylamine and butylamine (all at $5 \mathrm{mM}$ ) were tested as alternatives. PES and PMS concentrations were varied between $0.25 \mathrm{mM}$ and $5 \mathrm{mM}$. The only activity observed was a short period of ethanol-dependent dye reduction due to the presence of both $\mathrm{NAD}^{+}$-linked alcohol dehydrogenase (described below) and $\mathrm{NAD}^{+}$in the crude extracts. This activity was lost on dialysis and was increased in rate and extent by addition of more $\mathrm{NAD}^{+}$to the assay system.

All strains contained soluble $\mathrm{NAD}^{+}$-linked alcohol dehydrogenase after growth on ethanol but not after growth on succinate (Table 1). No activity was obtained with NADP ${ }^{+}$(tested with ethanol as substrate). No activity was present in membrane preparations although these contained an active 'NADH oxidase' system; these preparations therefore catalysed a rapid ethanol-dependent $\mathrm{O}_{2}$ consumption in the presence of added soluble fraction plus $\mathrm{NAD}^{+}$. 
More extensive work with crude soluble fractions from strains LMD 79.39 and NCIB 10694 showed that the $\mathrm{pH}$ optimum for both ethanol and $n$-octanol oxidation was about $\mathrm{pH} 9 \cdot 8$; typical bell-shaped curves were obtained with $50 \%$ of activity measured at $\mathrm{pH} 8 \cdot 8$ and $10 \cdot 8$.

The $K_{\mathrm{m}}$ values for $\mathrm{NAD}^{+}$were between $170 \mu \mathrm{M}$ and $330 \mu \mathrm{M}$ using both ethanol and $n$-octanol, and $\mathrm{NADP}^{+}$could not replace $\mathrm{NAD}^{+}$with either alcohol as substrate. Methanol $(15 \mathrm{~mm})$, propan-2-ol and aldehydes $\left(\mathrm{C}_{1}\right.$ to $\left.\mathrm{C}_{4}\right)$ were not substrates, but all normal aliphatic alcohols between $\mathrm{C}_{2}$ and $\mathrm{C}_{12}$ were oxidized at almost identical rates when high substrate concentrations were used. By contrast, when rates were measured with lowered substrate concentrations ( $1 \mathrm{mM}$ ), the normal aliphatic alcohols fell into two groups (short chain and longer chain), the relative rates being: ethanol, $100 \%$; propanol, $100 \%$; butanol, $33 \%$; pentanol, $13 \%$; hexanol, $43 \%$; heptanol, $46 \%$; octanol, $100 \%$, and nonanol, $100 \%$. The simplest interpretation of these results is that both strains of $A$. calcoaceticus contain two alcohol dehydrogenases. This conclusion is reinforced by the demonstration that the $K_{\mathrm{m}}$ values for ethanol, butanol, hexanol and octanol were $57-120 \mu \mathrm{M}, 3 \mathrm{mM}, 3 \mathrm{mM}$ and $100-160 \mu \mathrm{M}$ respectively, indicating that midchain length alcohols are not good substrates for either enzyme. It is probable that one of the dehydrogenases functions in the oxidation of ethanol during growth on that substrate, and the second functions in the oxidation of higher alcohols produced during growth on higher alkanes. If there are two separate enzymes, and not a single enzyme with an unusual substrate specificity, it is not obvious why both should be induced during growth on ethanol. This induction may be correlated with the gratuitous induction by ethanol of the emulsifying agent (emulsan) which is also only essential for growth on higher alkanes (Rubinovitz et al., 1982). It should be noted that the specific activities recorded were the correct order of magnitude to account for the growth rate on ethanol (doubling time between 1 and $3 \mathrm{~h}$ ); the minimum specific activity would need to be $156-470 \mathrm{nmol} \mathrm{min}{ }^{-1}(\mathrm{mg} \text { protein })^{-1}$, assuming that the bacteria are $50 \%$ carbon and $50 \%$ protein.

In summary, these results show that genuine strains of $\boldsymbol{A}$. calcoaceticus contain neither cytochrome $c$ nor a quinoprotein alcohol dehydrogenase but instead contain a typical $\mathrm{NAD}^{+}$linked ethanol dehydrogenase that could couple to the respiratory chain at a lower redox potential by way of NADH dehydrogenase. This conclusion is consistent with our expectation that all quinoprotein alcohol dehydrogenases are likely to be similar to methanol dehydrogenase in being coupled to the electron transport chain at the level of a high-potential cytochrome $c$.

We wish to thank the SERC for financial support; Mr S. A. Lawton for the work on the original strain LMD 79.39 in this laboratory and Dr J. A. Duine for useful discussions.

\section{REFERENCES}

ANThONy, C. (1982). The Biochemistry of Methylotrophs, pp. 219-244. London: Academic Press.

Baumann, P., Doudoroff, M. \& Stanier, R. Y. (1968a). Study of the Moraxella group. I. Genus Moraxella and the Neisseria catarrhalis group. Journal of Bacteriology 95, 58-73.

BaumanN, P., Doudoroff, M. \& Stanier, R. Y. $(1968 b)$. A study of the Moraxella group. II. Oxidasenegative species (Genus Acinetobacter). Journal of Bacteriology 95, 1520-1541.

BeARDMORE-Gray, M., O'KeEFFe, D. T. \& ANTHONY, C. (1983). The methanol:cytochrome $c$ oxidoreductase activity of methylotrophs. Journal of General Microbiology 129, 923-933.

BegGS, J. D. \& Fewson, C. A. (1977). Regulation of synthesis of benzyl alcohol dehydrogenase in Acinetobacter calcoaceticus NCIB 8250. Journal of General Microbiology 103, 127-140.

Bolbot, J. A. \& ANThony, C. (1980). The metabolism of 1,2-propanediol by the facultative methylotroph
Pseudomonas AM1. Journal of General Microbiology 120, 245-254.

BRADFORD, M. M. (1976). A rapid and sensitive method for the quantitation of microgram quantities of protein utilizing the principle of protein-dye binding. Analytical Biochemistry 72, 248-254.

Cross, A. R. \& ANTHony, C. (1980). The electron transport chains of the obligate methylotroph Methylophilus methylotrophus. Biochemical Journal 192, 429-439.

Duine, J. A. \& Frank, J., JzN (1981). Quinoprotein alcohol dehydrogenase from a non-methylotroph, Acinetobacter calcoaceticus. Journal of General Microbiology 122, 201-209.

Duine, J. A., Frank, J., JZN \& De Ruiter, L. G. (1979). Isolation of a methanol dehydrogenase with a functional coupling to cytochrome $c$. Journal of General Microbiology 115, 523-526.

Duine, J. A., Frank, J., JZN \& VAN DER MEER, R. (1982). Different forms of quinoprotein aldose- 
(glucose)-dehydrogenase in Acinetobacter calcoaceticus. Archives of Microbiology 131, 27-31.

ENSLey B. D., JR \& FinNeRTy, W. R. (1980). Influences of growth substrates and oxygen on the electron transport system of Acinetobactor sp. HO1N. Journal of Bacteriology 142, 859-868.

Fewson, C. A. (1966). Alcohol dehydrogenase activity of organism N.C.I.B. 8250. Biochemieal Journal 101, $21 \mathrm{P}$.

HENRICHSEN, J. (1972). Bacterial surface translocation: a survey and a classification. Bacteriological Reviews 36, 478-503.

Henriksen, S. D. (1973). Moraxella, Acinetobacter and the Mimeae. Bacteriological Reviews 37, 522-561.

Jones, C. W., Brice, J. M., Downs, A. J. \& Drozd, J. W. (1975). Bacterial respiration-linked proton translocation and its relationship to respiratory chain composition. European Journal of Biochemistry 52, 265-271.
Kennedy, R. S., Finnerty, W. R., Sudarsanan, K. \& Young, R. A. (1975). Microbial assimilation of hydrocarbons. I. The fine structure of a hydrocarbon-oxidising Acinetobacter sp. Archives of Microbiology 102, 75-83.

Rubinovitz, C., Gutnick, D. L. \& RosenberG, E. (1982). Emulsan production by Acinetobacter calcoaceticus in the presence of chloramphenicol. Journal of Bacteriology 152, 126-132.

TAUCherT, H., ROY, M., SCHÖPP, W. \& AURICH, H. (1975). Pyridinnucleotid-unabhängige Oxydation von längerkettigen aliphatischen Alkoholen durch ein Enzym aus Acinetobacter calcoaceticus. Zeitschrift für allgemeine Mikrobiologie 15, 457-460.

WhITTAKER, P. A. (1971). Terminal respiration in Moraxella lwoffi (NCIB 8250). Microbios 4, 65-70.

WIDDOwson, D. \& ANTHONY, C. (1975). The microbial metabolism of $\mathrm{C}_{1}$ compounds. The electron transport chain of Pseudomonas AM1. Biochemical Journal 132, 349-356. 